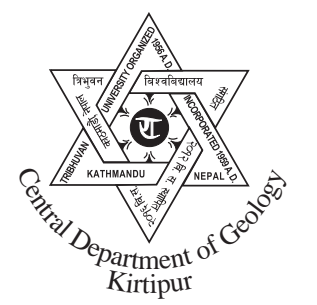

Bulletin of the Department of Geology

Bulletin of the Department of Geology, Tribhuvan University, Kathmandu, Nepal, vol. 18, 2015, pp. 67-74

\title{
Water quality of springs in Badigad Catchment, Western Nepal
}

\author{
*Jivan Bhusal and Prakash Gyawali \\ Central Department of Geology, Tribhuvan University, Kathmandu, Nepal
}

\begin{abstract}
Population growth and intense agricultural activities in Nepal has caused substantial increase in demand for fresh water. As there is limited access to surface water in most parts of the country, groundwater and springs are the principal water sources for irrigation and drinking purposes in the Terai and hilly region, respectively. The present study carries out the water quality analysis of 30 spring samples in the Badigad Catchment from Gulmi and Baglung Districts. The study was made to analyse suitability of spring waters of the Badigad Catchment for irrigation and drinking purposes. The physiochemical parameters were analysed using standard methods in the site and laboratory. Average value for $\mathrm{pH}$ of the sample was 7.8 with conductivity value ranging from 630 to $1500 \mathrm{micro}$ Siemens/cm. The bicarbonate alkalinity ranges from 140 to $350 \mathrm{mg} / \mathrm{L}$, indicating a medium salinity hazard in the catchment. The water in the catchment was found to be moderately hard with an average of $75 \mathrm{mg} / \mathrm{L} \mathrm{CaCO}_{3}$ hardness. Nitrate, sulphate, ammonia, chloride, fluoride and sodium absorption ratio were found to be $<0.1 \mathrm{mg} / \mathrm{L},<1 \mathrm{mg} / \mathrm{L},<1.5 \mathrm{mg} / \mathrm{L}, 3 \mathrm{mg} / \mathrm{L}, 1 \mathrm{mg} / \mathrm{L}$ and $<2$, respectively in all samples. Iron content in the water was also below the permissible limits in some samples and not available in some samples. Thus, the spring water in Badigad Catchment is suitable for drinking and irrigation purposes.
\end{abstract}

Key words: Badigad Catchment, Drinking water, Irrigation, Physical and chemical parameters, Water quality

Received: 5 March, 2015

Accepted: 4 June, 2015

\section{INTRODUCTION}

There has been a tremendous increase in demand for fresh water due to population growth and intense agricultural activities. Both the quality and the quantity of water resources are critical issues for agriculture and drinking purposes. Agricultural practice in Nepal is increasingly being dependent on irrigation, because of climatic constraints on crop demand. There is heavy reliance on the use of surface and groundwater for irrigation of crops. Thus irrigation is playing an increasingly important role in agricultural production. Irrigated agriculture makes a significant contribution to the Nepalese economy. It is one of the most important sectors which can contribute to the poverty reduction

*Corresponding author:

E-mail address: jivan.bhusal@hotmail.com strategy of the Government. Poor quality of water adversely affects human health and plant growth. In developing countries like Ghana, around $60 \%$ of all diseases are directly related to poor drinking water quality and poor sanitation. The World Health Organization (WHO) has repeatedly insisted that the single major factor adversely influencing the general health and life expectancy of population in many developing countries is lack of ready access to clean drinking water.

Irrigation is one of the most important factors for improvement of agricultural productivity. In Nepal most part of the country is not irrigated and depends upon the rainfall for production of crops. Productivity can be greatly increased by continuous supply of irrigation water. But long term irrigation also brings certain problems. The irrigation water contains small but 
appreciable amount of dissolved solids (salts of different types). These salts go into the soil along with the irrigation water. The effect of irrigation water quality is related to soils and crops it watered and its management. The chemical constituents of irrigation water can affect plant growth directly through toxicity or deficiency, or indirectly by altering plant availability of nutrients (Ayres and Westcot, 1985). High quality crops can be produced only by using high-quality irrigation water to keep other inputs optimal. Characteristics of irrigation water that define its quality vary with the source of the water. There are regional differences in their characteristics, based mainly on geology and climate (Islam and Shamsad, 2009). The suitability of water for irrigation is determined by its mineral constituents, the type of the plant and the soil to be irrigated. In fact, salts can be highly harmful. They can limit growth of plants physically by restricting the water absorption through modification of osmotic processes. Also salts may damage plant growth chemically by their effects of toxic substances upon metabolic processes. Salinity, sodicity/sodium hazard and toxicity generally need to be considered for evaluation of the suitable quality of springs for irrigation (Al-Bassam and Al-Rumikhani, 2003; Alexander and Mahalingam, 2011). As the study area lies in the rural hills of Nepal (Fig. 1), where most of the people consume direct water from the spring sources for drinking and irrigation purpose, study of the suitability of spring sources of water for irrigation and drinking purpose is very important. It is also very important to check whether the water quality is in compliance with the standards, and hence, suitable or not for the drinking and irrigational use. Thus the study was carried out to analyse water quality of different spring sources in the Badigad catchment in Gulmi and Baglung Districts for drinking and irrigation purpose.

\section{GEOLOGICAL SETTING}

The Badigad Catchment is bordered in the west by ther Jhimruk River, in the north by the Myagdi River, in the east by the Kaligandaki River and in the south by Ridhi River (Fig. 2). Thus the Badigad Catchment is one of the major tributaries of the Kaligandaki River and the

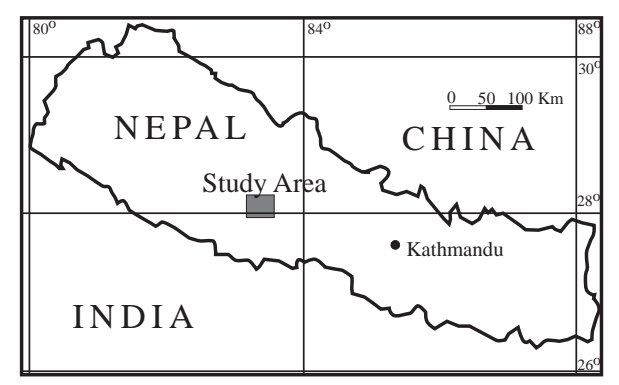

Fig. 1 Location map of the study area

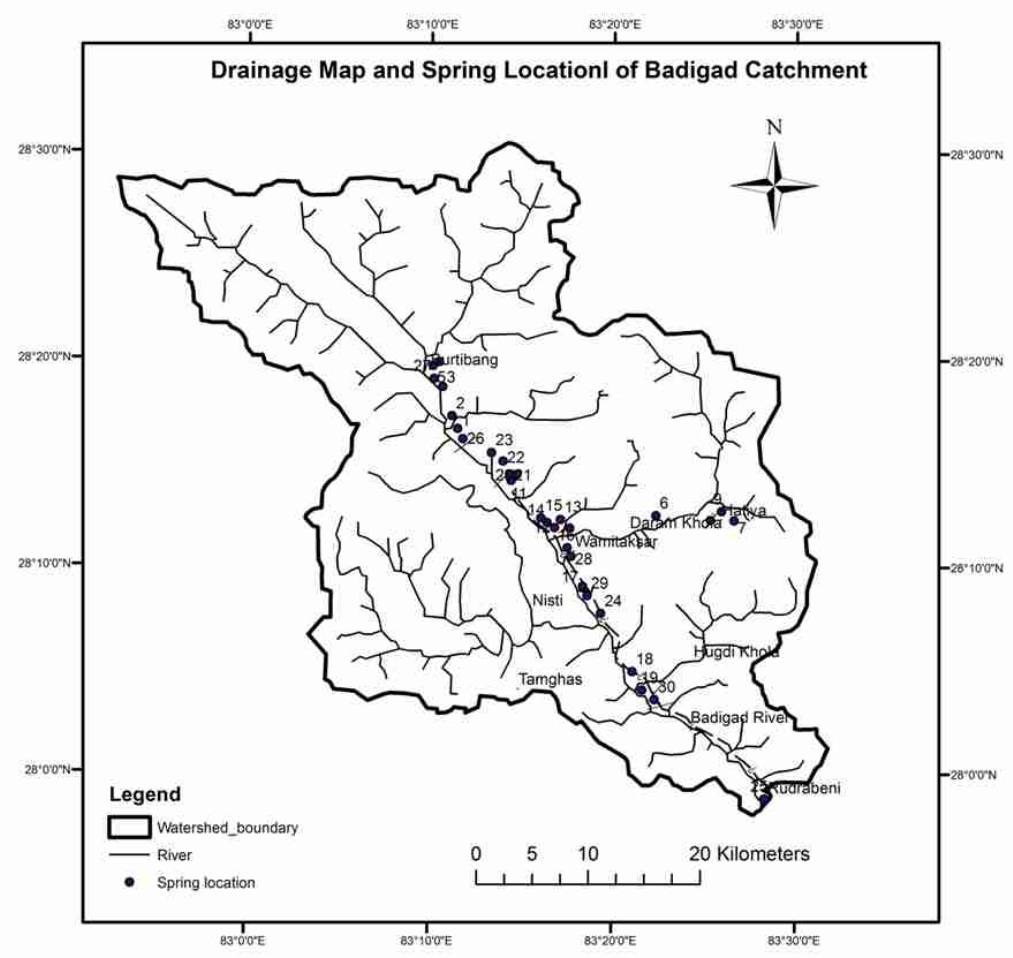

Fig. 2 Drainage map and location of the spring 


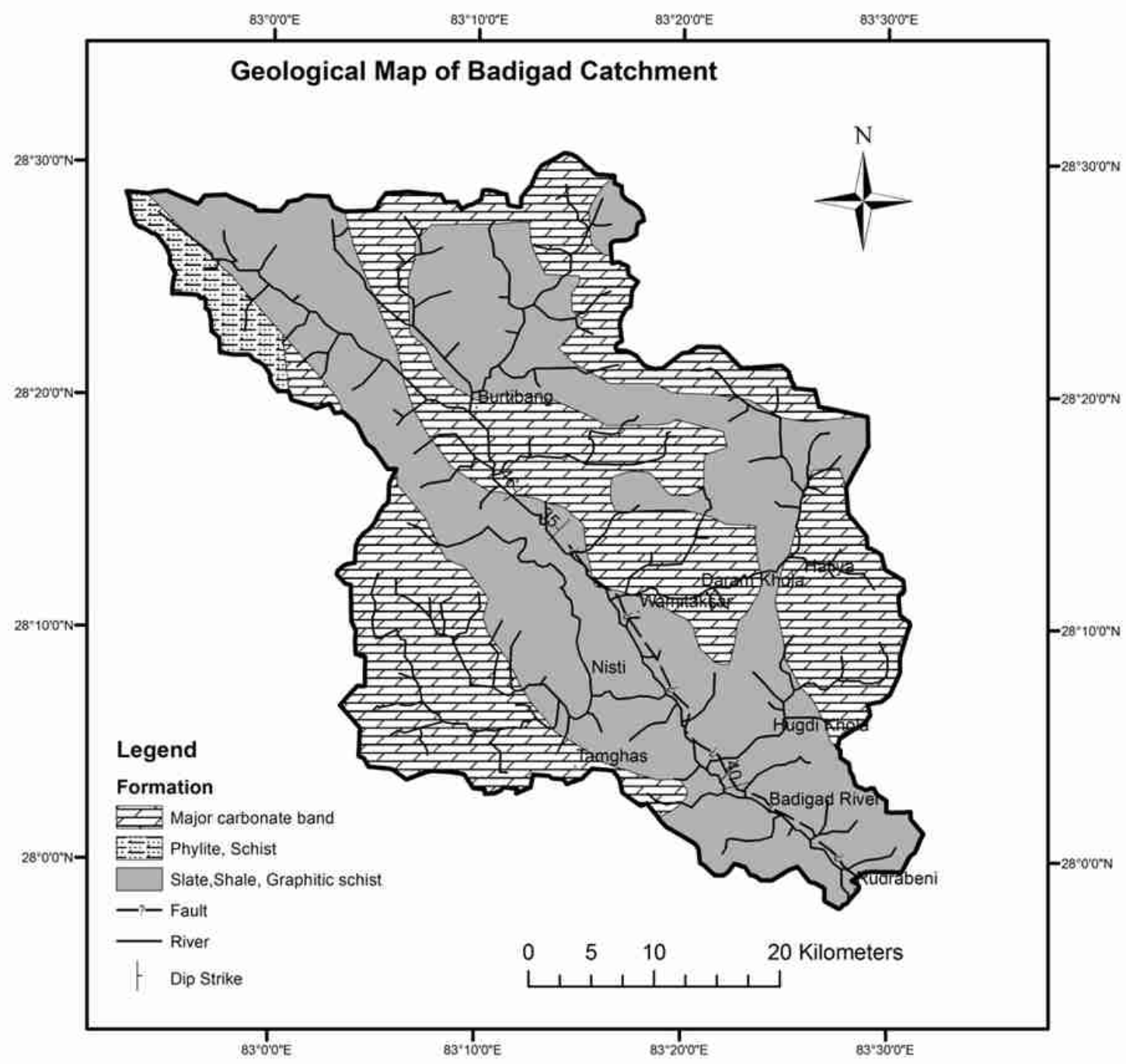

Fig. 3 Simplified Geological map of the Badigad Catchment area (Modified after Dhital 2015)

total catchment area of this river at Rudrabeni (confluence with the Kaligandaki River) is about 1961 square $\mathrm{km}$. The main tributaries of the Badigad River are the Daram Khola, the Chhaldi Khola and the Hugdi Khola. The highest elevation of the catchment is 4,016 m. The higher altitude areas are sparsely populated while the Middle Mountain areas are densely populated with extensive agricultural activities. The settlements are predominantly rural with very few urban and industrial sectors. The climate of the study area is sub- tropical. Average annual rainfall is $1900 \mathrm{~mm}$. Rainfall mainly occurs in monsoon, which provides $80 \%$ of total annual rain. The main monsoon crops are Paddy and Maize, while Wheat, Mustard, Lentil and to some extent vegetables are the winter crops. Monsoon crops are grown in between July and September whereas the winter crops are grown from September to March.

The Badigad catchment area lies in the Lesser Himalaya. The area comprises the low-grade, unfossiferous metamorphic rocks of slate (Benighat 
Slate), phyllite (Dandagaun Phyllite), quartzite and schist, and the sedimentary rocks of dolomite and limestone (Dhading Dolomite and Malekhu Limestone). The catchment area contains several faults including the Badigad Fault, thrusts and folds (Fig. 3). As distribution of geology is heterogeneous, availability of spring resources also varies within the catchment. Limestone is predominant in the spring resources than the rock formations (Benighat Slate, Dandagaun Phyllite and Nourpul Formation) mainly containing slate and phyllite.

\section{METHODS}

Thirty samples were collected during July to September 2015 and subjected to water quality analysis. All the samples were from springs (Table 1), which represented the Badigad River in western Nepal. Water samples from each source were collected aseptically in sterilized polypropylene bottles $(500 \mathrm{ml})$ for physicochemical analyses. Variables such as water temperature, $\mathrm{pH}$ and conductivity were measured in situ by using the specific electrodes. Parameters such as TDS, iron, nitrate, sulphate, chloride, ammonium, magnesium and

Table1: Location of different spring sources selected for samples

\begin{tabular}{|c|c|c|c|c|}
\hline $\begin{array}{l}\text { Sample } \\
\text { No. }\end{array}$ & $\begin{array}{l}\text { Sample } \\
\text { type }\end{array}$ & Location & District & $\begin{array}{l}\text { Description } \\
\text { (geology, land use, uses) }\end{array}$ \\
\hline SP-1 & Spring & Simle, Bhimgithe & Baglung & Fracture dolomite, forest and bush land, used for drinking and irrigation purpose \\
\hline SP-2 & Spring & Bhimphedi Bazaar & Baglung & Fracture dolomite, forest and bush land, used for drinking and irrigation purpose \\
\hline SP-3 & Dugwell & Rinam, Burtibang & Baglung & Colluvium, used for domestic purpose \\
\hline SP-4 & Dugwell & Burtibang, Simroad & Baglung & Fracture dolomite, forest and bush land, used for drinking and irrigation purpose \\
\hline SP-5 & Dugwell & Burtibang, Buspark & Baglung & No exposure, sample collected from tap \\
\hline SP-6 & Spring & Kandebas & Baglung & Colluvium deposits, spring originate from bamboo's tree, used by 20 households \\
\hline SP-7 & Spring & Hatiya Bazar & Baglung & Highly fractured slate/ phyllite, forest, drinking and domestic purpose \\
\hline SP-8 & Spring & Hatiya Bazar & Baglung & Highly fractured slate/ phyllite, forest, drinking and domestic purpose \\
\hline SP-9 & Spring & Hatiya Bazar & Baglung & highly fractured dolomite, forest, used for drinking purpose in Hatiya Bazar \\
\hline SP-10 & Spring & Hadikhola & Baglung & No exposure, colluvium, used for drinking and irrigation \\
\hline SP-11 & Spring & Gwalichaur & Baglung & Dolomite, forest, used for domestic purpose \\
\hline SP-12 & Spring & Kharbang & Baglung & Dolomite, forest, used for domestic purpose \\
\hline SP-13 & Spring & Kharbang & Baglung & Dolomite, forest, used for domestic purpose \\
\hline SP-14 & Spring & Raksey & Baglung & No exposure, cultivated land, irrigation and drinking \\
\hline SP-15 & Spring & Raksey & Baglung & Dolomite, forest, bush land, domestic uses \\
\hline SP-16 & Spring & Wamitaksar & Gulmi & Cultivated land, drinking purpose \\
\hline SP-17 & Spring & Bhuwachidi & Gulmi & Slate, forest, drinking and irrigation purpose \\
\hline SP-18 & Spring & Turang & Gulmi & Alluvial deposits, forest, drinking purpose \\
\hline SP-19 & Spring & Rupakot & Gulmi & Slate, cultivated land, irrigation purpose \\
\hline SP-20 & Spring & Gwalichaur & Baglung & Dolomite, bush land, grassland, drinking purpose \\
\hline SP-21 & Spring & Gwalichaur & Baglung & Colluvium, bush land, drinking purpose \\
\hline SP-22 & Spring & Gwalichaur-2 & Baglung & Dolomite, forest, drinking and irrigation purpose \\
\hline SP-23 & Spring & Gwalichaur-1 & Baglung & Cultivated land, drinking and domestic uses \\
\hline SP-24 & Spring & Indrigauda & Gulmi & Cultivated land, bush land, drinking and domestic purpose \\
\hline SP-25 & Spring & Rudrabeni & Gulmi & Dolomite, cliff, used for drinking purpose \\
\hline SP-26 & Spring & Simle & Baglung & No exposure, colluvium, cultivated land, drinking \\
\hline SP-27 & Spring & Rinam, Burtibang & Baglung & Colluvium, drinking and domestic purpose \\
\hline SP-28 & Spring & Wamitaksar & Gulmi & Slate, forest, drinking purpose \\
\hline SP-29 & Spring & Bhuwachidi & Gulmi & No exposure, cultivated land, drinking purpose \\
\hline SP-30 & Spring & Rupakot & Gulmi & No exposure, alluvium deposits, drinking purpose \\
\hline
\end{tabular}


Table 2: Methods used for the physiochemical analysis of the sample (APHA, 1995)

\begin{tabular}{ll}
\hline Parameters & Methods \\
\hline $\mathrm{Ph}$ & Electrometric \\
$\mathrm{EC}$ & Electrometric \\
Iron & Spectrophotometric (Phenanothroline) \\
Hardness & Titration(EDTA) \\
Alkalinity & Titration(HCL) \\
Nitrate & Spectrophotometric \\
Sulphate & Spectrophotometric(Barium Chloride) \\
Chloride & Titration (Argentometric) \\
Ammonia & Spectrophotometric (Nessler`s) \\
Sodium & Flame photometer \\
Calcium & Titration (EDTA) \\
Magnesium & Titration (EDTA) \\
\hline
\end{tabular}

Table 3: WHO standard and Nepal standard for drinking and irrigation water

\begin{tabular}{|c|c|c|c|c|}
\hline \multirow[t]{2}{*}{ Parameters } & \multirow[t]{2}{*}{ Units } & \multicolumn{2}{|c|}{$\begin{array}{l}\text { Drinking } \\
\text { Water } \\
\text { Standards }\end{array}$} & \multirow{2}{*}{$\begin{array}{c}\text { Irrigation } \\
\text { Water } \\
\text { standards } \\
\text { NS }\end{array}$} \\
\hline & & NS & WHO & \\
\hline $\mathrm{pH}$ & & $6.5-8.5$ & $6.5-8.5$ & $6.5-8.5$ \\
\hline Lab temperature & ${ }^{0} \mathrm{C}$ & & & \\
\hline Ammonia & $\mathrm{mg} / \mathrm{l}$ & 1.5 & & \\
\hline Iron & $\mathrm{mg} / \mathrm{l}$ & 0.3 & 0.03 & 5 \\
\hline Total & $\mathrm{mg} / \mathrm{l}$ & 500 & 500 & \\
\hline Calcium Hardness & $\mathrm{mg} / \mathrm{l}$ & 150 & 150 & \\
\hline Magnesium Hardness & $\mathrm{mg} / \mathrm{l}$ & 150 & 150 & \\
\hline Electric Conductivity & $\mu \mathrm{S} / \mathrm{cm}$ & 1500 & 500 & $40 \mu \mathrm{S} / \mathrm{m}$ \\
\hline Total Alkalinity & $\mathrm{mg} / \mathrm{l}$ & 500 & 500 & \\
\hline Bicarbonate Alkalinity & $\mathrm{mg} / \mathrm{l}$ & & & \\
\hline Carbonate Alkalinity & $\mathrm{mg} / \mathrm{l}$ & & 200 & \\
\hline Hydroxide Alkalinity & $\mathrm{mg} / \mathrm{l}$ & & & \\
\hline Chloride & $\mathrm{mg} / \mathrm{l}$ & & 250 & 100 \\
\hline Nitrate & $\mathrm{mg} / \mathrm{l}$ & 50 & 10 & \\
\hline Nitrite & $\mathrm{mg} / \mathrm{l}$ & & 3 & \\
\hline Phosphate & $\mathrm{mg} / \mathrm{l}$ & & & \\
\hline Sulphate & $\mathrm{mg} / \mathrm{l}$ & 250 & 400 & \\
\hline Sodium & $\mathrm{mg} / \mathrm{l}$ & & 200 & 70 \\
\hline Potassium & $\mathrm{mg} / \mathrm{l}$ & & & \\
\hline Arsenic & $\mathrm{mg} / \mathrm{l}$ & 0.05 & 0.05 & 0.1 \\
\hline $\begin{array}{l}\text { Total Dissolved } \\
\text { solid }\end{array}$ & $\mathrm{mg} / \mathrm{l}$ & 1000 & 500 & $40 \mu \mathrm{S} / \mathrm{m}$ \\
\hline
\end{tabular}

calcium were also analysed in the laboratory using the standard methods (APHA, 1995). The respective methods used for the physiochemical parameters are mentioned in Table 2. The tolerence values of WHO and National Standard for Drinking and Irrigation (NSDI) (Table 3) were taken to compare ther results of the present study.

\section{RESULTS}

In total 30 samples were taken from the various springs of the catchment. Among them 12 springs lies in dolomite, 7 in slate/phyllite, 9 in colluvium and 2 in alluvium. Similarly, most of the springs 18 originate from forest area, 7 from cultivation land and remaining 5 originate from grass land bush land.

The average value for $\mathrm{pH}$ of the sample was 7.8 and the electrical conductivity value ranged from 630 to 1500 micro Siemens/cm. The bicarbonate alkalinity ranged from 140 to $350 \mathrm{mg} / \mathrm{L}$, indicating a medium salinity hazard in the catchment. The water in the catchment was found to be moderately hard with an average of $75 \mathrm{mg} / \mathrm{L} \mathrm{CaCO}_{3}$ hardness. Nitrate, sulphate, ammonia, chloride, fluoride and sodium absorption ratio were $<0.1 \mathrm{mg} / \mathrm{l},<0.1 \mathrm{mg} / \mathrm{L},<1 \mathrm{mg} / \mathrm{L},<1.5 \mathrm{mg} / \mathrm{L}$, $3 \mathrm{mg} / \mathrm{L}, 1 \mathrm{mg} / \mathrm{L}$ and $<2$ respectively in all samples. Iron content in the water was also below the permissible limits in some samples and not available in some samples. None of the spring samples as well as ground water samples violated National Drinking Water Standards (NDWS) for electrical conductivity (EC), total dissolved solids (TDS), total suspended solids (TSS), appearance, chloride and nitrate. Similarly, none of the samples violated the standards for total hardness (TH) indicating soft nature of the water. The spring samples were within the NDWS for manganese (Mn) and iron $(\mathrm{Fe})$ whereas $15.4 \%$ and $39.0 \%$ of the ground water samples violated the standards for manganese and iron, respectively (Table 4)

Although, most of the sample spring shows the chemical parameters within the permissible limit of drinking water standard and irrigation water standard, but some variation was identified with the lithological changes. Arsenic, phosphate, nitrate, nitrite and ammonia had similar value, and iron content found in few spring originated from dolomite. Potassium, 
Table 4: Result of water analysis of various parameters

\begin{tabular}{|c|c|c|c|c|c|c|c|c|c|c|c|c|c|c|c|c|}
\hline \multirow{2}{*}{ Parameters } & \multirow{2}{*}{ unit } & \multicolumn{15}{|c|}{ Sample No. } \\
\hline & & 1 & 2 & 3 & 4 & 5 & 6 & 7 & 8 & 9 & 10 & 11 & 12 & 13 & 14 & 15 \\
\hline pH & & 8 & 7.8 & 7.8 & 7.5 & 7.3 & 7.2 & 7.4 & 7.6 & 7.6 & 7.6 & 7.9 & 8.1 & 8.1 & 8.1 & 8.1 \\
\hline $\mathbf{T}$ & ${ }^{0} \mathrm{C}$ & 20.8 & 20.8 & 20.8 & 20.8 & 20.8 & 20.8 & 20.8 & 20.8 & 20.8 & 20.8 & 20.8 & 20.8 & 20.8 & 20.8 & 20.8 \\
\hline NH3 & $\mathrm{mg} / \mathrm{l}$ & $\mathrm{N}$ & $\mathrm{N}$ & $\mathrm{N}$ & 0.1 & 0.2 & $\mathrm{~N}$ & 0.2 & $\mathrm{~N}$ & $\mathrm{~N}$ & 0.7 & 1.1 & 1.1 & 1.4 & 0.5 & $\mathrm{~N}$ \\
\hline $\mathrm{Fe}$ & $\mathrm{mg} / \mathrm{l}$ & 0.1 & $\mathrm{~N}$ & $\mathrm{~N}$ & $\mathrm{~N}$ & $\mathrm{~N}$ & $\mathrm{~N}$ & $\mathrm{~N}$ & $\mathrm{~N}$ & 0.1 & $\mathrm{~N}$ & $\mathrm{~N}$ & $\mathrm{~N}$ & $\mathrm{~N}$ & $\mathrm{~N}$ & $\mathrm{~N}$ \\
\hline TH & $\mathrm{mg} / \mathrm{l}$ & 340 & 360 & 280 & 160 & 100 & 220 & 280 & 260 & 180 & 320 & 280 & 200 & 380 & 260 & 240 \\
\hline $\mathrm{Ca}$ & $\mathrm{mg} / \mathrm{l}$ & 112 & 100 & 76 & 44 & 26 & 60 & 76 & 72 & 44 & 100 & 104 & 56 & 112 & 56 & 60 \\
\hline Mg & $\mathrm{mg} / \mathrm{l}$ & 14.6 & 26.8 & 22.0 & 12.2 & 8.5 & 17.1 & 22.0 & 19.5 & 17.1 & 17.1 & 4.9 & 14.6 & 24.4 & 29.3 & 22.0 \\
\hline $\begin{array}{l}\text { EC } \\
\text { Total }\end{array}$ & $\mu \mathrm{S} / \mathrm{m}$ & 250 & 310 & 310 & 130 & 120 & 210 & 170 & 170 & 170 & 270 & 320 & 290 & 290 & 290 & 280 \\
\hline Alkalinity & $\mathrm{mg} / \mathrm{l}$ & 210 & 200 & 245 & 210 & 230 & 190 & 180 & 185 & 210 & 200 & 180 & 150 & 190 & 185 & 155 \\
\hline $\mathrm{HCO}_{3}$ & $\mathrm{mg} / \mathrm{l}$ & 210 & 200 & 245 & 210 & 230 & 190 & 180 & 185 & 210 & 200 & 180 & 150 & 190 & 185 & 155 \\
\hline $\mathrm{CO}_{3}$ & $\mathrm{mg} / \mathrm{l}$ & 0 & 0 & 0 & 0 & 0 & 0 & 0 & 0 & 0 & 0 & 0 & 0 & 0 & 0 & 0 \\
\hline OH & $\mathrm{mg} / \mathrm{l}$ & 0 & 0 & 0 & 0 & 0 & 0 & 0 & 0 & 0 & 0 & 0 & 0 & 0 & 0 & 0 \\
\hline $\mathrm{Cl}$ & $\mathrm{mg} / \mathrm{l}$ & 3.2 & 3.1 & 2.9 & 3.2 & 2.8 & 3.4 & 3.5 & 2.9 & 2.8 & 2.7 & 2.5 & 2.6 & 3.1 & 3.2 & 2.9 \\
\hline $\mathrm{NO}_{3}$ & $\mathrm{mg} / \mathrm{l}$ & $<0.1$ & $<0.1$ & $<0.1$ & $<0.1$ & $<0.1$ & $<0.1$ & $<0.1$ & $<0.1$ & $<0.1$ & $<0.1$ & $<0.1$ & $<0.1$ & $<0.1$ & $<0.1$ & $<0.1$ \\
\hline $\mathrm{NO}_{2}$ & $\mathrm{mg} / \mathrm{l}$ & $<0.1$ & $<0.1$ & $<0.1$ & $<0.1$ & $<0.1$ & $<0.1$ & $<0.1$ & $<0.1$ & $<0.1$ & $<0.1$ & $<0.1$ & $<0.1$ & $<0.1$ & $<0.1$ & $<0.1$ \\
\hline $\mathrm{PO}_{4}$ & $\mathrm{mg} / \mathrm{l}$ & $<0.1$ & $<0.1$ & $<0.1$ & $<0.1$ & $<0.1$ & $<0.1$ & $<0.1$ & $<0.1$ & $<0.1$ & $<0.1$ & $<0.1$ & $<0.1$ & $<0.1$ & $<0.1$ & $<0.1$ \\
\hline $\mathrm{SO}_{4}$ & $\mathrm{mg} / \mathrm{l}$ & $<1$ & $<1$ & $<1$ & $<1$ & $<1$ & $<1$ & $<1$ & $<1$ & $<1$ & $<1$ & $<1$ & $<1$ & $<1$ & $<1$ & $<1$ \\
\hline $\mathrm{Na}$ & $\mathrm{mg} / \mathrm{l}$ & 6.1 & 4.1 & 3.8 & 3.9 & 7.4 & 2.5 & 3.9 & 3 & 3.3 & 3.4 & 7.1 & 4.1 & 3.9 & 5.8 & 2.5 \\
\hline $\mathbf{K}$ & $\mathrm{mg} / \mathrm{l}$ & 0.7 & 1.2 & 0.1 & 2.1 & 1.8 & 0.9 & 0.8 & 0.2 & 0.5 & 3.1 & 1.5 & 1.2 & 0.8 & 2.1 & 1.8 \\
\hline As & $\mathrm{mg} / \mathrm{l}$ & $<0.01$ & $1<0.01$ & $1<0.01$ & $\mid<0.01$ & $\mid<0.01$ & $\mid<0.01$ & $\mid<0.01$ & $<0.01$ & $1<0.01$ & $<0.01$ & $1<0.01$ & $1<0.01$ & $1<0.01$ & $1<0.01$ & $1<0.01$ \\
\hline TDS & $\mathrm{mg} / \mathrm{l}$ & 250 & 290 & 300 & 140 & 130 & 200 & 170 & 110 & 170 & 160 & 290 & 270 & 270 & 260 & 260 \\
\hline
\end{tabular}




\begin{tabular}{|c|c|c|c|c|c|c|c|c|c|c|c|c|c|c|c|c|}
\hline \multirow{2}{*}{ Parameters } & \multirow[t]{2}{*}{ unit } & \multicolumn{15}{|c|}{ Sample No. } \\
\hline & & 16 & 17 & 18 & 19 & 20 & 21 & 22 & 23 & 24 & 25 & 26 & 27 & 28 & 29 & 30 \\
\hline pH & & 7.7 & 8 & 8 & 8 & 7.8 & 8.2 & 8 & 8 & 7.9 & 8 & 8.3 & 8 & 8 & 8 & 6.4 \\
\hline $\mathbf{T}$ & ${ }^{0} \mathrm{C}$ & 20.8 & 20.8 & 20.8 & 20.8 & 20.8 & 20.8 & 20.8 & 20.8 & 20.8 & 20.8 & 20.8 & 20.8 & 20.8 & 20.8 & 20.8 \\
\hline NH3 & $\mathrm{mg} / \mathrm{l}$ & 1.1 & $\mathrm{~N}$ & 1.4 & 1.5 & 1.1 & $\mathrm{~N}$ & $\mathrm{~N}$ & $\mathrm{~N}$ & 1.2 & 1.4 & $\mathrm{~N}$ & $\mathrm{~N}$ & 0.5 & 0.5 & 18 \\
\hline $\mathrm{Fe}$ & $\mathrm{mg} / \mathrm{l}$ & $\mathrm{N}$ & $\mathrm{N}$ & $\mathrm{N}$ & $\mathrm{N}$ & 0.9 & $\mathrm{~N}$ & $\mathrm{~N}$ & $\mathrm{~N}$ & $\mathrm{~N}$ & $\mathrm{~N}$ & $\mathrm{~N}$ & $\mathrm{~N}$ & $\mathrm{~N}$ & $\mathrm{~N}$ & 15.6 \\
\hline TH & $\mathrm{mg} / \mathrm{l}$ & 320 & 200 & 300 & 200 & 300 & 280 & 220 & 340 & 380 & 350 & 200 & 180 & 130 & 160 & 240 \\
\hline $\mathbf{C a}$ & $\mathrm{mg} / \mathrm{l}$ & 76 & 44 & 96 & 64 & 92 & 98 & 64 & 84 & 100 & 108 & 44 & 40 & 32 & 36 & 60 \\
\hline Mg & $\mathrm{mg} / \mathrm{l}$ & 31.7 & 22.0 & 14.6 & 9.8 & 17.1 & 8.5 & 14.6 & 31.7 & 31.7 & 19.5 & 22.0 & 19.5 & 12.2 & 17.1 & 22.0 \\
\hline EC & $\mu \mathrm{S} / \mathrm{m}$ & 360 & 290 & 370 & 340 & 340 & 200 & 330 & 300 & 370 & 340 & 150 & 150 & 160 & 160 & 270 \\
\hline $\begin{array}{l}\text { Total } \\
\text { Alkalinity }\end{array}$ & $\mathrm{mg} / \mathrm{l}$ & 140 & 160 & 150 & 140 & 180 & 150 & 210 & 200 & 160 & 180 & 155 & 140 & 200 & 250 & 350 \\
\hline $\mathrm{HCO}_{3}$ & $\mathrm{mg} / \mathrm{l}$ & 140 & 160 & 150 & 140 & 180 & 150 & 210 & 200 & 160 & 180 & 155 & 140 & 200 & 250 & 350 \\
\hline $\mathrm{CO}_{3}$ & $\mathrm{mg} / \mathrm{l}$ & 0 & 0 & 0 & 0 & 0 & 0 & 0 & 0 & 0 & 0 & 0 & 0 & 0 & 0 & 0 \\
\hline $\mathbf{O H}$ & $\mathrm{mg} / \mathrm{l}$ & 0 & 0 & 0 & 0 & 0 & 0 & 0 & 0 & 0 & 0 & 0 & 0 & 0 & 0 & 0 \\
\hline Cl & $\mathrm{mg} / \mathrm{l}$ & 2.8 & 2.5 & 3.5 & 3.4 & 2.6 & 2.6 & 3.2 & 3.1 & 3 & 3.2 & 3.2 & 3.1 & 3.2 & 2.8 & 15.8 \\
\hline $\mathrm{NO}_{3}$ & $\mathrm{mg} / \mathrm{l}$ & $<0.1$ & $<0.1$ & $<0.1$ & $<0.1$ & $<0.1$ & $<0.1$ & $<0.1$ & $<0.1$ & $<0.1$ & $<0.1$ & $<0.1$ & $<0.1$ & $<0.1$ & $<0.1$ & $<0.1$ \\
\hline $\mathrm{NO}_{2}$ & $\mathrm{mg} / \mathrm{l}$ & $<0.1$ & $<0.1$ & $<0.1$ & $<0.1$ & $<0.1$ & $<0.1$ & $<0.1$ & $<0.1$ & $<0.1$ & $<0.1$ & $<0.1$ & $<0.1$ & $<0.1$ & $<0.1$ & $<0.1$ \\
\hline $\mathrm{PO}_{4}$ & $\mathrm{mg} / \mathrm{l}$ & $<0.1$ & $<0.1$ & $<0.1$ & $<0.1$ & $<0.1$ & $<0.1$ & $<0.1$ & $<0.1$ & $<0.1$ & $<0.1$ & $<0.1$ & $<0.1$ & $<0.1$ & $<0.1$ & $<0.1$ \\
\hline $\mathrm{SO}_{4}$ & $\mathrm{mg} / \mathrm{l}$ & $<$ & $<$ & $<$ & $<$ & $<$ & $<$ & $<$ & $<$ & $<$ & $<$ & $<$ & $<$ & $<$ & $<$ & $<$ \\
\hline $\mathrm{Na}$ & $\mathrm{mg} / \mathrm{l}$ & 2.8 & 6.4 & 2.6 & 3.1 & 3.2 & 5.5 & 7.3 & 6.5 & 7.5 & 7.3 & 6.6 & 6.8 & 5.1 & 7.1 & 9.8 \\
\hline $\mathbf{K}$ & $\mathrm{mg} / \mathrm{l}$ & 0.9 & 0.8 & 0.2 & 0.5 & 3.1 & 0.9 & 1.2 & 0.8 & 2.1 & 1.8 & 0.9 & 0.8 & 0.2 & 0.5 & 3.1 \\
\hline As & $\mathrm{mg} / \mathrm{l}$ & $<0.0$ & $<0.0$ & $\mid<0.01$ & $\mid<0.01$ & $\mid<0.01$ & $<0.01$ & $<0.01$ & $<0.01$ & $<0.01$ & $<0.01$ & $<0.01$ & $<0.01$ & $<0.01$ & $\mid<0.01$ & $1<0.01$ \\
\hline TDS & $\mathrm{mg} / \mathrm{l}$ & 330 & 260 & 310 & 310 & 310 & 190 & 280 & 260 & 300 & 300 & 130 & 140 & 150 & 160 & 270 \\
\hline
\end{tabular}


sodium and chlorite had no distinct variation whereas hardness of water was slightly high in the spring from dolomite and limestone.

\section{CONCLUSIONS}

1. The water quality of spring resources of the Badigad Catchment was found under the permissible limit of the National Standard for Drinking and Irrigation (NSDI) and WHO standards for drinking and irrigation water.

2. Spring originated from non-carbonate rocks have slightly lower value of chemical parameters than those from the carbonate rocks.

\section{ACKNOWLEDGEMENT}

Authors would like to thank Central Department of Geology, Tribhuvan University and Ground Water Research Development Board for their generous support. We would also like to thank to Lifeline Laboratory (Kupondol, Lalitpur) for providing laboratory facilities. We are thankful to Mr. Krishna Upadhyaya and Mr. Sunil Shanker Pradhananga for their valuable assistance during this works. Wewould like to thank the local people of Baglung and Gulmi districts for their great cooperation in the field.

\section{REFERENCES}

Al-Bassam, A.M. and Al-Rumikhani, Y.A., 2003. "Integrated hydro-chemical method of water quality assessment for irrigation in arid areas: Application to the hill aquifer, Saudi Arabia", Journal of African Earth Sciences,v. 36, pp.345-356. https://doi.org/10.1016/S08995362(03)00046-0

APHA, 1992. Standard methods for the examination of water and wastewater, American Journal of Water Resources, 18th Edition American Public Health Association, Washington, DC, 541p. DOI: 10.12691/ajwr$1-3-3$

Ayers, R.S., and Westcot, D.W., 1985. Water Quality for Agriculture, FAO Irrigation and Drainage Paper 29 rev 1. FAO, UN, Rome, 174p.

Dhital, M.R., 2015. Geology of the Nepal Himalaya, Regional Perspective of the Colloidal Orogen, Springer.

Environment statistics of Nepal 2008, Government of Nepal National Planning Commission Secretariat Central Bureau of Statistics Kathmandu, Nepal. 177p.

Islam, M.S. and Shamsad, S.Z.K.M., 2009. Assessment of irrigation water quality of Bogra district in Bangladesh. Bangladesh Journal of Agricultural Research. V. 34, pp. 597-608.

WHO, 1996. Guidelines for Drinking-water Quality. Health criteria and other supporting information, World Health Organization, Geneva, 2nd ed. Vol. 2. 94p. 